\title{
Weathering the Storm: Talent Management in Internationally Oriented Greek Small and Medium-Sized Enterprises
}

\begin{abstract}
Purpose - Based on a study of internationally oriented Greek small and medium-sized enterprises (SMEs), and using the lens of institutional theory, this article extends our understanding of the extent to which Greece's institutional context influences talent management (TM). In so doing, we focused on key TM practices employed by SMEs to enhance and sustain TM: talent acquisition, development and retention. We also explore how these practices are shaped by the Greek institutional context.
\end{abstract}

Design/methodology/approach - Employing a multiple case-study approach, we conducted 18 interviews in six distinctive SMEs operating in north, central and southern Greece. The data was thematically analysed to identify patterns across all SMEs.

Findings - We found that unlike multinational corporations (MNCs), internationally oriented Greek SMEs adopt a more inclusive approach to TM practices as well as that the country's institutional context presented important yet not deterministic hurdles. We also found that SMEs adopt an opportunistic approach to talent acquisition by utilising appropriate available sources to reach out for available talent. We provided evidence that SMEs adopt a hybrid approach to talent development in addressing talent scarcity. Finally, we reported that talent retention is significantly appreciated by SMEs, who offer a range of intrinsic and extrinsic incentives to retain their talented workforce.

Originality - In a context of reforms, we report on TM practice in internationally oriented Greek SMEs. We also add to the literature on TM in SMEs by providing evidence on the conceptualisation and management of global talent in this context.

\section{Paper type - Research paper}

Keywords: Talent management, institutional theory, international small and medium-sized enterprises, Greece 


\section{Introduction}

Given the fiercely challenging global business environment, companies are forced to be pragmatic and strategic in order to remain competitive (Newell, 2005). One of the ways they achieve this is by optimising their talented human capital (Carbery, 2015) on a global scale. This area has seen a worldwide renaissance of interest in the worker-workplace equation; all kinds of organisations have recognised the need to manage their workforce effectively, regardless of context-specific economic and workforce conditions (Tarique and Schuler, 2010). In today's hyper-change environment, TM is seen by many organisations as being necessary in order to generate a competitive advantage (e.g. Harsch and Festing, 2020).

The bulk of TM studies are in the context of MNCs (Stahl et al., 2012), although there is currently significant interest in the SMEs context as well (e.g. Festing et al., 2013). Research suggests that the conceptualisation and practice of TM in SMEs is different to that of MNCs. This is due to significant differences between the contexts such as the latter's primary focus on high potentials and high performers (Cappelli and Keller, 2014). SMEs, on the other hand, are typified by an egalitarian culture, lack of stable hierarchical structures and strategic positions, and the enactment of informal and often personalised practices (Krishnan and Scullion, 2017). It is therefore necessary for TM to be uniquely conceptualised in this context. In the context of SMEs, TM is viewed as a philosophy relevant for all employees but which focuses mostly on those with high potentials and in critical positions, with the aim to get talents on board, grow their optimal capabilities and retain them (Piansoongnern et al., 2011).

Evidence from European SMEs could advance the academic discourse on how TM is implemented in this context (Skuza et al., 2016), as well as encourage practitioners to revisit practices related to talent acquisition, development and retention (Kirk et al., 2020). Research on Greek SMEs in particular is necessary for a number of reasons. First, current evidence on TM in European SMEs is concentrated in Germany (e.g. Festing et al., 2013), Spain (e.g. Valverde et al., 2013) and Slovakia (Savov et al., 2020); there has been limited thorough investigation of Greek SMEs, despite the fact that they represent a large share of European firms (Statista, 2021). Second, the aftermath of the 2007/2008 economic recession precipitated significant reforms in employment relations, which distinguished Greece from other Mediterranean countries in terms of legislation (Psychogios et al., 2014). Third, Greece has experienced a significant emigration of its educated youth (Theodoropoulos et al., 2014) but is currently planning to attract young talent back to the country through governmental schemes 
(Stamouli, 2020). Fourth, many industries face the major challenge of talent shortage, where there is a mismatch between the competences of graduates and the needs of the labour market, resulting in the talents of many graduates being underutilised (OECD, 2018a). Greek SMEs account for $99 \%$ of all organisations operating in the country (Theriou and Chatzoudes, 2015); the institutional context thus has important implications for such SMEs. This study aims to establish the extent to which the Greek institutional context influences the nature and practice of TM among SMEs with an international outlook that operate in the country. The key research objective is:

- To examine the extent to which Greece's institutional context shapes talent acquisition, development and retention among SMEs in the country.

Overall, our study contributes to the limited European literature on TM in SMEs by adducing evidence from internationally oriented Greek SMEs, as well as highlighting important lessons on how European SMEs can remain competitive during periods of quick reforms. Drawing on studies focusing on the contextual nature of TM (e.g. Gallardo-Gallardo et al., 2020) and building on institutional theory, we first provide empirical evidence on how internationally oriented Greek SMEs responded to institutional challenges by investing in TM and secondly highlight the changing meaning of talent in SMEs. Empirically, we show how

TM practices in SMEs are embedded in the organisational context and how, in practice, hybrid approaches are used. This suggests that in practice, inclusive and exclusive categorisations may become blurred. Finally, we expand the body of knowledge on TM in SMEs by specifying methods of talent acquisition, development and retention.

\section{Theoretical background}

\section{Talent management and institutional theory}

Existing literature on TM shows that it lacks a robust theoretical and empirical basis (Nijs et al., 2014). There are some theoretical perspectives that could explain how, and why, TM is pursued by organisations; these include the institutional theory, the resource-based view and the human capital theory (Khilji and Schuler, 2017).

In this study, we focus on the institutional perspective, for several reasons. First, differences in institutional settings among countries affect the nature and embeddedness of their people management policies and practices (Paauwe and Boselie, 2003). Vaiman and 
Brewster (2015) thus argue that TM strategies need to consider the institutional context in which decisions are made. Second, research studies have shown that institutional forces are a key determinant of TM in SMEs (Krishnan and Scullion, 2017); this perspective is therefore likely to be key for our study. Overall, the use of institutional theory will help to provide a comprehensive picture of the TM phenomenon (Beamond et al., 2016).

Institutional theory was developed to offer a powerful explanation for individual and organisational actions (Dacin et al., 2002). Institutions shape actions by demanding accountability and providing the standards by which people and organisations recognise the achievements of others (Morgan and Hauptmeier, 2014). This being the case, institutional theory was designed to account for the powerful ways in which institutions drive change and shape the contexts in which organisations operate. Specifically, institutional theory suggests that organisations do not operate in vacuums but rather in socially constructed environments; that they seek legitimisation and approval from different stakeholders (Jackson and Schuler, 1995), and that their practices conform to a range of sociocultural, technological, legal, economic and other forces (Boon et al., 2009). Institutional forces may also exert different influences on larger vs smaller firms; the former often use formal TM practices that help them to increase their legitimacy and enhance talent attraction, whereas SMEs tend to initiate informal TM practices and acquire talent from informal sources (Krishnan and Scullion, 2017).

Organisations thus respond to institutional pressures in different ways (Oliver, 1991) and enjoy some leeway in their approach to TM. The role of factors such as human agency, leadership, the financial health of the company and the existence of HR managers should not be overlooked (Boon et al., 2009). In other words, institutional pressures are not deterministic but are rather affected by key decision makers including CEOs and HR managers, and there is scope for strategic choice in terms of the implementation of practices (ibid.). In their responses, organisations may be seen as 'leaders', 'followers' or 'laggards', depending on whether they adopt innovative, reactive or passive responses to institutional pressures (Mirvis, 1997). Thus, by utilising the theoretical perspective of institutional theory and the scope for strategic choice in implementation, this study aims to establish the extent to which the nature and practice of TM among internationally oriented Greek SMEs are influenced by the country's institutional context. In the following section, we discuss Greece's institutional environment and broad employee management factors, which may have affected TM in the country's SMEs.

\section{Greece's institutional environment}


In 2007/2008, Greece was strongly affected by the global financial crisis, which led to explosive public debt and huge budget deficits, as well as exposing the problem of tax evasion (Eibel, 2015). To avoid default, three MoUs were agreed in 2010, 2012 and 2015 between the Greek government and the European 'Troika' (comprised of the European Commission, European Central Bank and the International Monetary Fund). These involved multi-billion loan agreements in exchange for changes in economic and financial policies, draconian austerity measures, labour law reforms, and privatisation of state assets (European Commission, 2017). During this period, most macroeconomic, social and health indicators dramatically declined (Kretsos and Vogiatzoglou, 2015). GDP dropped by 25\% since 2008 (OECD, 2016), and approximately half of private sector workers' salaries were below the poverty line for a family of four (OECD, 2018b). Furthermore, the shrinking economy dramatically affected employment in the country, raising the youth unemployment rate to $50 \%$ by the end of 2015 (OECD, 2018b) and contributing to the 'brain drain' emigration of 450,000 mostly young and skilled workers.

The Greek crisis had a strong institutional dimension (Vlados and Chatzinikolaou, 2020) due to the country's weak institutional system. Analysts highlighted a number of 'civic pathogenies' including political corruption, populism, clientelistic relations with specific interest groups (Theocharis and Deth, 2015), the asymmetrical institutional framework of the Eurozone (Pagoulatos, 2020), and Greece's competitiveness model (Pitelis, 2012). Some argue that the country still suffers from 'institutional deficit' and view Greece as a rather closed economy whose extractive institutions discourage innovation and entrepreneurship; the country is also seen as suffering from excessive and low-quality regulation, and a slow judicial system (Hatzis, 2018).

During this important period for Greece, a number of significant institutional changes and restructurings were implemented (Vlados and Chatzinikolaou, 2020). The Troika deemed the Greek labour market to be overly regulated, and in order to rectify the situation, they instituted a set of major labour market reforms (OECD, 2018b). Widescale wage reductions were implemented, collective agreements were frozen and collective bargaining was decentralised (OECD, 2018b). Temporary contracts became more common, dismissals thresholds were relaxed and private employment agencies were allowed to recruit workers to temporary positions (ibid.). As a result, the number of atypical contracts increased, with a growing share of jobs becoming temporary or part-time and paid at the minimum wage, leading 
to a 'pandemic of work precariousness' (Kretsos and Vogiatzoglou, 2015, p. 220). Some believed that Greece had become a laboratory for neoliberal policies (Eibel, 2015).

Compared to the institutional environments in other European countries, which supported SMEs in employee management issues (e.g. Germany; see Festing et al., 2013), Greece's institutional changes drove many Greek SMEs to bankruptcy (Sainis et al., 2017). In response to the challenges of the country's institutional environment, Greek SMEs used informal practices (Tsilika et al., 2020) in the employee management area. Although empirical studies on Greek SMEs have been limited to HRM areas (see Stavrou and Papalexandris, 2016), it has been suggested that the lifeline to sustainability for Greek SMEs was their talented employees, who generally have a good work ethic, are goal-oriented, team players, extroverts, adaptable and intelligent (Marinakou and Giousmpasoglou, 2019). This suggests the need to investigate the role of talents in SMEs in responding to Greece's institutional environment.

In conclusion, Greece has been exposed to major structural and institutional changes agreed between the national government and the Troika, geared towards liberalisation, deregulation and labour market flexibility. In this environment, many companies in Greece, including SMEs, responded with restrictive measures (Correia et al., 2015). These included payroll cost adjustments, hiring freezes, redundancies and training budget cuts, reflecting the adjustments businesses made to HRM practices and internal employment systems in order to survive (Teague and Roche, 2014). Unsurprisingly, Greek employees working under these conditions showed lower levels of job satisfaction, commitment and morale (Markovits et al., 2017). Having gone through waves of political, economic and social turmoil (European Commission, 2017), the county has since been on track to recovery (OECD, 2018b).

\section{Talent management in SMEs}

From an operational perspective, companies either consider all staff as talent who can contribute to organisational goals (i.e. inclusive TM) or exclusively invest in their top performers/potential, from whom they can expect faster and higher returns (i.e. exclusive TM) (Gallardo-Gallardo et al., 2013). In the case of SMEs, exclusive TM does not fit with the egalitarian culture, which values teamwork and flexibility; more inclusive approaches to TM are therefore more commonly adopted, reflecting the belief of SMEs in the potential of all employees to add value (Krishnan and Scullion, 2017). In Germany, for example, Festing et al. (2013) found that a majority of surveyed SMEs adopted an inclusive TM approach, enacting 
TM practices that targeted the whole workforce; in Spain, Valverde et al. (2013) suggested that SMEs appear to adopt a hybrid approach.

For SMEs, the implementation of informal, flexible and personalised practices gives a much-needed competitive advantage (Dundon and Wilkinson, 2009), as well as reducing costs and securing organisational flexibility (Jack et al., 2006). In addition, SMEs rarely use formal talent identification, preferring to rely on informal practices to identify talented employees (Valverde et al., 2013). This serves to protect employee morale and teamwork (Krishnan and Scullion, 2017), highlighting the fact that a more inclusive approach to TM is a better fit in this context. Informal TM practices are employed by SMEs for the purposes of talent acquisition, development and retention (Sparrow et al., 2014); these shall be examined below.

\section{Talent acquisition in SMEs}

TM policies increasingly focus on developing both employee value propositions and employer brands in order to source the best talent available (Martin and Sinclair, 2019). Since there is increasing competition for the best talent, developing a strong employer image is essential, and many companies invest heavily in promoting themselves as being one of the best places to work (Sparrow and Makram, 2015).

Although employee value prepositions and employer brands are important, they are challenging for SMEs. Although research on talent acquisition in SMEs is limited, studies suggest that SMEs lack visibility, resources (Storey et al., 2010) and legitimacy, thus limiting the information available to their potential talent pool (Williamson et al., 2002). In addition, SMEs tend to recruit in separate talent pools than those of MNCs and large firms (ibid.). They also adopt fit-to-context talent acquisition methods that are not included in the best practices' 'package' utilised by MNCs (Krishnan and Scullion, 2017). There is also heavy reliance on informal talent attraction, e.g. word of mouth, friends and relatives (Festing et al., 2013).

\section{Talent development in SMEs}

Talent development is a key element of the TM process (Cappelli, 2009) and should be dynamic and linked with the strategic trajectory of the organisation. A key issue in talent development is whether companies make or buy talent. The latter has become more common but is unlikely to be successful in the long term (Bidwell, 2011). Developing talent internally is effective in 
addressing both employee and organisational needs (Sparrow et al, 2014); it also enhances the gaining of organisational knowledge (Lepak and Snell, 1999), as well as helping to make succession planning more effective (Gandz, 2006).

Talent development is also important in ensuring both the current and future supply of talented employees at the organisational level (Vaiman et al., 2018). It seeks to provide job and career-related competency for individuals and involves a range of practices, including leadership development programmes, mentoring and team working (Bjorkman et al, 2017). Talent development could particularly assist SMEs in training employees to fill various strategic roles as the business expands (Heneman et al., 2000). To date, there is little empirical research on how SMEs develop their talents. This study will explore this area in the context of internationally oriented Greek SMEs.

\section{Talent retention in SMEs}

Since talent scarcity and growing competition for talent are growing challenges for employers worldwide, retaining talent is a critical TM challenge (D'Amato and Herzfeldt, 2008). This is actually one of the main reasons why organisations set up and invest resources in TM systems (Holland and Scullion, 2021). It is, however, far from clear as to just how effective companies are in retaining talent and developing effective talent pipelines (Martin and Schmidt, 2010).

The fact that talent is becoming increasingly mobile, together with the erosion of loyalty and traditional psychological contracts, makes talent retention increasingly challenging (Pate and Scullion, 2018). The costs of replacing talent—which may involve loss of expertise and client relationships - can be considerable, and those with the most marketable skills are the most likely to leave first (Holland and Scullion, 2021). An increasing number of organisations, including SMEs, use several strategies to minimise turnover. These include compensation and benefits, organisational environment, promotion of work-life balance (Sparrow et al., 2014) and additional non-monetary rewards (Silzer and Dowell, 2010). There has been little research on the factors affecting talent retention in SMEs; this study will explore this area in the context of internationally oriented Greek SMEs.

\section{Methodology, data collection and analysis}

\section{Method}


This study adopted a qualitative multiple case-study approach, which is suitable as it enables researchers to both understand and analyse the nature of particular practices implemented in the real business environment (Holliday, 2002). According to Miles and Huberman (1994), a qualitative, exploratory approach to research enables researchers to access new and rich (raw) data, which is necessary for gaining more nuanced insights into the subject of inquiry (Wöcke et al., 2007).

Given that that there is no global consensus about the definition of SMEs (Krishnan and Scullion, 2017), when identifying the study sample, we chose to follow similar TM studies completed in the European SME context (e.g. Festing et al., 2013). We adopted the European Commission's (2020) definition, according to which SMEs are considered companies whose balance sheet total is $€ 43$ million or less and with a maximum of 250 employees. This definition further distinguishes between micro (maximum 10 employees), small (11-50 employees) and medium (51-250 employees) companies; our sample falls within the medium-sized category, which employs a growing segment of the active European population (Valverde et al., 2013) and whose TM practices are more sophisticated (Festing et al., 2013; Savov et al., 2020).

We used cluster probability sampling to identify our sampled companies. This method was appropriate because personal contact with the sample was necessary for the completion of interviews (Saunders et al., 2009); it also enabled us to geographically cover the whole country. Greece was divided into the northern, central and southern clusters. In selecting cases for our sample, the inclusion requirements for SMEs were:

(1) to be global competitors and operating in Greece,

(2) to have remained profitable despite the tough economy. either by generating innovative products/services (i.e. leaders) or by adopting innovative technologies (i.e. adopters; Voumvaki et al., 2020),

(3) to implement TM policies and/or practices,

(4) to be staffed by between 50-249 employees (European Commission, 2020).

We identified six companies that satisfied the inclusion criteria and represented various industries. This increased the reliability and validity of cross-case comparisons (Bryman, 2012; see Table 1). They were all innovative SMEs - either leaders or adopters-with global presence and who worked predominantly with clients outside Greece. In response to Greece's significant 'brain drain', which saw mass emigration of mostly young and skilled individuals 
(OECD, 2018b), the distinctive sampled companies implemented TM with the aim to attract, develop and retain talented Greeks with working experience abroad and who could satisfy their global clients' expectations.

\section{[Insert Table 1 about here]}

\section{Data collection}

In line with studies on TM in the context of SMEs (e.g. Chung and D'Announzio-Green, 2018; Festing et al., 2013), we interviewed the CEO, the HR manager and a line manager of each business, as these individuals are the most knowledgeable about HR-related company issues. In SMEs, top managers have overall control of employee management decisions, whichalong with the informal nature of practices - enhance the resilience of growing SMEs to deploy talents (Heneman et al., 2000). They are also viewed as strategic figures in planning and implementing TM practices in SMEs (Cardon and Stevens, 2004), given the business size and the inability to have specialised HR departments (Krishnan and Scullion, 2017). Top managers thus make a significant contribution to the enactment of TM practices (Joyce and Slocum, 2012).

Prior to the interviews, several meetings were held with the top management of all the sample businesses in which it was established that the selected interviewees participate in the design and/or enactment of TM. In total, 18 semi-structured interviews were conducted, satisfying the suggested threshold (see Saunders and Townsend, 2016). For the interviews, we used key terminology to ensure shared understanding of core concepts among all participants. We also followed a precise interview protocol, which mirrored our study's objective (Bryman, 2012). The interview protocol began with questions on the companies' backgrounds and then focused on talent acquisition, development and retention practices. The interviews lasted approximately 90 minutes each and were conducted in Greek, before being manually transcribed and translated to English by two of the co-authors, who are fluent in both languages and have widely published qualitative studies in high-impact journals. Their multilingual expertise helped to ensure that none of the meaning was lost in translation (Xian, 2008).

\section{Data analysis}


To synthesise the data, we employed Braun and Clarke's (2006) thematic analysis procedure (TAP). This is a qualitative method used for identifying, analysing and reporting themes within data by going back and forth between datasets. Following the pattern of Pratt et al. (2006), we operationalised the process by adopting three key steps.

First, we created tentative categories using first-order codes, followed by a process of data reduction through open coding. This was achieved by analysing textual content and creating words and phrases that helped to convey the salient, summative, and essence-catching features of interview excerpts (Braun and Clarke, 2006; Pratt et al., 2006) and directly address the question of our study (Patton, 1990). Relying on Miles and Huberman's (1994) qualitative analytical approach, and using the respondents' summary forms, we recorded tentative categories that emerged from the dataset at each point in time. In doing so, we found data excerpts that related to our key research question. In response to this question, provisional descriptions from data excerpts (the closed economy, unwillingness to invest and labour laws, among others) first suggested the country's institutional context, but also other themes including online advertisingand referral — which align with known talent acquisition methods (see Table 2). For talent development, the provisional responses uncovered department level, employee level, training method and evaluation, among others, all of which are subject to Greece's institutional constraints (Vlados and Chatzinikolaou, 2020). Following the naming of codes and construction of categories, we reviewed the data carefully to make sure that crucial narratives, accounts and excerpts fit well within each category.

Secondly, we proceeded to creating theoretical categories by consolidating first-order codes that emerged from the interview data in each category. This captured variables such as 'macroeconomic decline', 'recruitment methods', 'idiosyncratic qualities', 'selection method', 'training need identification', 'training frequency', 'training target group' and 'on-the-job'; among others. As Pratt et al. (2006, p. 240) advised, this step allowed our first-order coding to become 'more theoretical and more abstract'.

We then took the third and final step of the process, consolidating the conceptual categories. This helped to generate theoretical clarification for the manifestation of the phenomenon under inquiry (Braun and Clark, 2006; Pratt et al., 2006). The process enabled us to uncover key themes pertaining to how Greece's institutional context influences talent acquisition, development and retention. We continued to cross-compare and validate the 
conceptual categories of the process until we finally agreed on these key themes of our study, which are informed by the dataset (Braun and Clark, 2006).

[Insert Table 2 about here]

\section{Findings}

\section{Talent acquisition in the institutional context of Greek SMEs}

According to our findings, internationally oriented Greek SMEs use a mix of informal recruitment and selection methods to acquire talent, rather than adopting sophisticated methods of talent acquisition as do MNCs (Krishnan and Scullion, 2017). All the sampled SMEs invest substantially in advertising vacancies on job websites while simultaneously depending on university contacts, referrals from current staff and recruitment agencies:

We initially advertise a job opening online in various job websites as well as we derive $C V$ from universities. We also make this job opening known to our staff with a notice on the bulletin board and ask them for referrals. If none of the applicants is qualified, we might also use external recruitment agencies (HR Manager C).

In addition, the majority of the investigated SMEs primarily use face-to-face interviews to select potential talent. For positions that require particular expertise, they conduct multiple interview sessions, including aptitude tests and telephone interviews:

Since people with specific expertise should fill all positions in our company, we follow three stages. At a first stage, successful candidates attend face-to-face interviews with one of our senior managers who check their technical knowledge through practical exercises. I will then face-to-face interview those who successfully passed the first stage aiming to determine their communication and technical skills. At a third stage, our American partner will complete a telephone interview with the finalists to check their capacity and ability to handle challenging technical issues (CEO B).

There could be three explanations as to why SMEs adopt a less strategic approach to talent acquisition, all of which relate to institutional context. The first of these relates to the Greek institutional environment, which is characterised by reforms (Vlados and Chatzinikolaou, 2020), renewal of temporary contracts, relaxed dismissals (OECD, 2018b) and 
increases in the number of temporary or part-time members of the workforce who earn a minimum wage (Kretsos and Vogiatzoglou, 2015). These factors may all serve to deter talented individuals who are considering employment in Greek SMEs. Greek SMEs need to develop a talented workforce who can develop innovative products/services and meet the needs of their global clients (Voumvaki et al., 2020); they must therefore utilise a range of sources to attract scarce talent, often including flexible and personalised approaches (Dundon and Wilkinson, 2009). This explains the creative talent acquisition practices commonly used by SMEs to attract talent from diverse talent pools (Krishnan and Scullion, 2017).

Second, SMEs may lack expertise in acquiring talent (Festing et al., 2013) and adopting a strategic approach in this area. Third, important TM decisions are usually taken by SMEs' top management (Jack et al., 2006). In Greek's institutional context, which drove many SMEs to bankruptcy (Sainis et al., 2017), some internationally oriented SMEs may have prioritised the restructuring of the business over more systematic-yet costly-approaches to talent acquisition.

When looking for idiosyncratic qualities in potential talent, the majority of the sampled SMEs looked for individuals who possess a combination of skills (e.g. communication skills, customer-service skills), personality traits (e.g. confident, kind, smiley) and a particular character (e.g. passionate about their job):

We are looking for people who are honest, kind and have passion for their job (CEO A).

Apart from the basic and relevant to the job knowledge, a successful applicant should be able to communicate well and demonstrate confidence in doing their job appropriately. This is key for our business (CEO C).

We are searching for warm people. To put it simply, we are looking for smiley people (Line Manager E).

Due to the nature of our job, we are looking for people who possess excellent customer service skills (CEO F).

This is evidence that in Greek SMEs, it is an individual's unique attributes, and not the critical position they hold, that mainly define talent. This is in line with the general 
conceptualisation of talent in the SME context (see Krishnan and Scullion, 2017). One possible interpretation of this rather subjective approach to talent might be that in an institutional environment of reforms such as that of Greece (Vlados and Chatzinikolaou, 2020), what is considered a critical position today might well vary from what will be considered a key position tomorrow. It is also possible to explain that since Greek SMEs work in a volatile environment where changes are common, it is imperative to have a workforce that is good natured, skilled and adaptable.

\section{Talent development in the institutional context of Greek SMEs}

When discussing the issue of talent development, the majority of respondents reported that although developmental opportunities are offered to all staff, they are driven by employee and/or departmental training needs. This is consistent with a hybrid approach to TM (Valverde et al., 2013) and suggests that talent development addresses deficits stemming from changes in the institutional environment. The majority of our respondents argued that although all employees receive continuous general training, it is likely that this training will be on an adhoc tailored basis:

It is a given that we offer opportunities for development to all employees regardless of their position, such as general training during the induction period. The nature of the training obviously depends on a department's or employee's needs (HR Manager F).

An additional point made by all respondents was that training mainly takes place through ad-hoc seminars, followed by coaching and on-the-job training:

All employees are supported to attend external seminars, for example delivered by universities. As the manager of the front-office department, I also have the responsibility to coach my team and arrange for senior staff to show to new employees how to accomplish particular tasks related to their job (Line Manager F).

Despite the difficulties of Greece's economic climate, the sampled SMEs offered learning and training to their employees not only to meet business needs, but also out of a sense of duty:

In Greece, we believe we must do more to enhance development in talent and innovation. I mean, despite the economic down-turn and other sociocultural norms and 
constraints, we, as international corporations, must do what is needed. We have to lead change, and that is why we must invest in talent development (CEO A).

Formal planning and implementation of developmental initiatives are unlikely to be present in SMEs, possibly because their structure and operations largely depend on institutional parameters that interplay. For example, in order to deal with the country's austerity measures and new tax requirements (Tsilika et al., 2020), many Greek SMEs proceeded to strategically restructure their businesses (Sainis et al., 2017), downsizing their training departments and investing less in training. Larger organisations generally adopt a more strategic approach to talent development (Savov et al., 2020). SMEs, however, tended to employ talent development methods that were more flexible and tailored to their own needs (Chung and D'AnnounzioGreen, 2018), while at the same time-given the external environmental pressures - also seeking to reduce costs.

Moreover, the majority of interviewees argued that post-training evaluations take place at the learning level, and are aimed at identifying discrepancies between training expectations and outcomes:

Training is evaluated by both the trainer and the trainees. We ask for this to see if trainees improved their performance after successfully completing the training (HR Manager A).

Investment in talent development is a significant TM practice for internationally oriented Greek SMEs. In an institutional environment known for its draconian austerity measures and labour law reforms (European Commission, 2017), we found evidence that Greek SMEs may have viewed talent development as an alternative to financial incentives. This has also been found in other countries where firms responded to the institutional environment by developing staff internally (Heneman et al., 2000), an effective and cost-efficient approach to addressing talent scarcity (Festing et al., 2013). SMEs may therefore view talent development as a vehicle to address the ever-changing needs of both companies and their staff (Sparrow et al, 2014).

\section{Talent retention in the institutional context of Greek SMEs}


In the context of a country with high youth unemployment, significantly depletion of the workforce due to brain-drain, and a considerable portion of private-sector employee salaries below the poverty line (OECD, 2018b), the sampled Greek SMEs highlighted that talent retention was a priority for them. All 18 interviewees claimed that both intrinsic and extrinsic incentives are offered to their whole workforce. While inclusive talent retention methods may be a product of the SME egalitarian culture in general (Krishnan and Scullion, 2017), SMEs in Greece recognise that talented employees are scarce, have been invested in and are at risk of being lost to competitors; businesses were therefore particularly eager to retain talent.

When our company is at a stage where it is neither profitable nor productive, then employees feel insecure, lose interest and search for jobs in other similar companies. Monetary and non-monetary incentives are offered to all employees because they assist us in building internal talent capacity (Line Manager C).

In addition, performance evaluations are subjective indicators, and an exclusive approach to talent retention could have a negative impact on employee morale (GallardoGallardo et al., 2013). In order for SMEs to retain expertise and client relationships (Holland and Scullion, 2021) while simultaneously protecting employee morale (Krishnan and Scullion, 2017), they may have chosen to develop effective talent pipelines (Martin and Schmidt, 2010) by inclusively offering incentives. Unsurprisingly, bonuses, competitive salaries and health insurance packages dominated extrinsic rewards, while intrinsic rewards included training opportunities, promotions, good relationships with top management and recognition. In line with Chung and D'Announzio-Green's (2018) assertion that SMEs compensate their inability to offer financial incentives with non-financial rewards, our informants reported that for SMES, the importance of intrinsic rewards often outweighs that of extrinsic incentives; this was due in part to the mutual realisation that due to financial constrains (Theriou and Chatzoudes, 2015), resources were limited:

In 2011, our company was financially devastated by the 2007/2008 economic recession. However, no employee quitted or was made redundant. Although increments in salaries or bonuses were impossible, we offered to our personnel additional training opportunities. Such an incentive led to $100 \%$ talent retention, because our personnel appreciated that we support their continuous professional development despite the challenging business environment. Good relationships with top management are undoubtedly an additional vehicle in retaining our staff (HR Manager A). 
We offer a range of financial and non-financial rewards to our people, e.g. competitive salary, health insurance, training opportunities and promotions. Under current circumstances, we managed to retain employees mainly by providing them some sort of ownership (HR Manager E).

Recognition, training opportunities and bonuses are the key 'ingredients' of our retention pack (Line Manager $\mathrm{A})$.

Talent retention was regarded as a key issue for the SMEs in the study. This was unsurprising, as regardless of their size, all organisations compete for talent globally (D'Amato and Herzfeldt, 2008). But Greece's institutional environment also played an important role. The significant decline of macroeconomic indicators (Kretsos and Vogiatzoglou, 2015), as well as the radical labour law reforms (European Commission, 2017), created a large outflow of youth talent to other countries (OECD, 2018b). SMEs with an international outlook therefore invested heavily in incentives to retain talent, including monetary and non-monetary (e.g. bonuses and training opportunities) rewards.

\section{Discussion}

TM is increasingly important for SMEs, as it assists them in attracting, recruiting, developing and retaining talents (Piansoongnern et al., 2011). However, there is still a dearth of research in this area in European SMEs (Krishnan and Scullion, 2017). Aiming to contribute to this field, we focused on the major choices made by internationally oriented Greek SMEs with regard to talent acquisition, development and retention, seeking to glean information about how they managed to remain competitive. Drawing on institutional theory, we made a distinctive contribution to the literature on TM in SMEs by providing a comprehensive picture of how the Greek institutional context - an environment of ongoing liberalisation reforms, strict austerity measures and talent scarcity — had a profound yet indeterministic influence on the nature and practice of TM among its internationally oriented SMEs.

With regards to talent acquisition in the institutional context, we found that faced with the outflow of youth talent, internationally oriented Greek SMEs employ a variety of informal, cost-sensitive and often personalised methods of talent acquisition. A significant finding that contradicts Valverde et al. (2013) is that the conceptualisation of talent in Greek SMEs was not linked to their key positions but rather to more general criteria, indicating that talent equals the unique attributes of individual employees that fit into a specific life stage of an SME (Krishnan 
and Scullion, 2017). Both skills (such as customer service and communication skills) and personal traits (such as confidence, honesty and passion) were key criteria in determining talent, suggesting a divergence from the conceptualisation of talent in larger Greek-based companies (see Marinakou and Giousmpasoglou, 2019).

Our research also highlighted that internationally oriented Greek SMEs invest significantly in informal, cost-effective methods of training and development, despite the highly volatile institutional context forcing many organisations to dramatically reduce their training expenditure. This distinctive group of internationally oriented Greek SMEs continued investing in talent development, driven both by employee and departmental needs. They utilised mainly ad-hoc seminars, coaching and on-the-job training. By embracing internal talent development in difficult times, these SMEs gained the benefits of a high-skilled workforce (Sainis et al., 2017), addressed talent shortages within the sector (Theriou and Chatzoudes, 2015) and not least won the appreciation of their workforce. In some respects, investment in talent development was viewed as an alternative incentive offered to talented workers, which could also assist SMEs in addressing wider TM challenges (Sparrow et al., 2014) resulting from institutional forces.

Our findings also indicate that talent retention is a key issue for this distinctive group of Greek SMEs, which they seek to address by offering both intrinsic and extrinsic incentives to their workforce. SMEs tend to approach talent retention with an inclusive and egalitarian perspective, geared at for reducing turnover and maintaining a positive relationship with workers (Holland and Scullion, 2021). Having invested substantial effort in attracting and developing talent - in a particularly challenging external environment that discourages entrepreneurship - the SMEs in our study placed strong emphasis on talent retention (Hatzis, 2018), ensuring that they held on to talents who could meet their global clients' expectations.

We have already noted that organisations respond to institutional pressure in different ways (Oliver, 1991), and as Boon et al. (2009) assert, how they implement TM is largely determined by the role of human agency, as well as additional factors such as leadership, the company's financial health and the modus operandi of the HR managers. This was true for the Greeks SMEs in our study, who-despite the challenging business environment of economic hardships and ethical breakdown (Tasoulis et al., 2019) — chose to invest in inclusive TM practices, rather than downsizing and laying off employees. This shows that although institutional pressures matter, they were not entirely deterministic in this case. We conclude 
that TM decisions are mostly linked to key decision makers, including CEOs and HR managers. The SMEs in our study may thus be regarded as 'innovators' compared to other Greek SMEs (Oliver, 1991).

\section{Implications for theory and practice}

This study provides empirical evidence of TM practice in Greek SMEs who were able to withstand the country's institutional context. It extends TM literature in that it determines the TM nature and practices embedded in SMEs. Our study has made a theoretical contribution in this context, exploring the practices of talent acquisition, development and retention adopted by the sampled SMEs, all of whom were influenced by the institutional context (Krishnan and Scullion, 2017) yet were able to respond as 'innovators', persevering in their emphasis on TM. Our study highlights the distinctive nature of TM in the SME context, shedding light on an important and relatively underexplored area and contributing to knowledge of the discipline.

In addition to the conceptual contribution, our study also highlights important practical implications for stakeholders-SMEs, HR practitioners and policymakers-for how the institutional dynamic may affect TM practices. As our findings suggest, as a response to adversity, successful companies have recognised that building human capacity is key to success (Sainis et al., 2017). This study provides stakeholders with insights into how effective TM practices can be considered a lifeline to organisational sustainability-particularly for SMEs in the contemporary challenging and fiercely competitive business environment (Krishnan and Scullion, 2017). This highlights the potential of inclusive TM practices to be part of an effective workforce management strategy: relative to the prevailing institutional dynamic, stakeholders (policymakers and HR practitioners) must engage in the multiple areas of individual talent acquisition, development and retention.

The study also suggests that an inclusive TM approach can be strategic when it fits with the business strategy and organisational culture, and that senior SME managers choose this approach to managing talent because it fits better within their organisational context. Elitist or exclusive TM strategies can undermine employee morale, particularly in the case of untalented workers. Such approaches are therefore inappropriate, and indeed rare, in the SME context (Krishnan and Scullion, 2017). Another reason for this is the fact that such strategies carry an additional cost due to the huge investment required for the strategic development of identified talents (Chung and D'Announzio-Green, 2018). 
It must, however, be noted that in a volatile business environment, organisational disruption and change can force SMEs into adopting cost-cutting mechanisms that can reduce investment in the training and development of talented employees in key operational areas (Jiang and Iles, 2011). Therefore, in order to ensure that efforts towards talent acquisition, development and retention are not undermined by short-term pressures, SMEs must endeavour to meet their needs in cost-effective ways while at the same time placing egalitarian and inclusive emphasis at the forefront of their TM practice (Collings and Mellahi, 2009). Organisational commitment to egalitarian and inclusive emphasis is crucial in the TM effort; in addition to enhancing employees' buy-in and perception of being valued, it also increases their commitment and retention, as well as the release of the unique knowledge and skills that the talent possesses (Ogbonna and Harris, 2015). In summary, we suggest that inclusive TM is a strategic approach for effective TM implementation in SMEs.

\section{Limitations and directions for future research}

The current study shows that contemporary businesses have experienced a transition period, which necessitated considering an inclusive TM approach to help build and sustain human capacity (Krishnan and Scullion, 2017). However, our data do not show the extent to which this was influenced by internal and/or external elements. Indeed, this transition may have been caused by a wide range of factors, such as culture, legislation, technology, increased immigration and skill shortage (Holland and Scullion, 2021). Future research could explore the extent to which these or other factors served to impact this transition. At any rate, the SMEs studied have already adapted to the contemporary reality and built effective TM strategies to deal with all of these contextual elements.

Moreover, the sample size of 18 respondents from six distinctive Greek SMEs may be considered relatively small and not representative of all Greek SMEs, which may limit the development of holistic and generalised conclusions from our findings. Additionally, following relevant extant research in the SME context (e.g. Chung and D'Announzio-Green, 2018), we chose to explore the topic mainly from a managerial perspective; this was because top management can provide valuable insights on HR-related issues-especially in the context of SMEs, where decision-making is centralised (Heneman et al., 2000). Although our rigorous data analysis procedure helped to minimise these shortfalls, we suggest that future studies compare the voices from multiple organisational actors, including talents and non-talents. The present study would also benefit from additional quantitative data from more firms. A study of 
Greek subsidiaries of MNCs, for example, would provide an important perspective and help facilitate the generalisation of findings (Wöcke et al., 2007).

\section{Conclusion}

In conclusion, our paper explored the extent to which the Greek institutional context influences TM among internationally oriented Greek SMEs. In this context, the study contributed to the conceptualisation and definition of TM. It provided empirical evidence that talent in this context was not related to key positions but rather to an individual's unique attributes - a combination of skills, personality and character traits - such as passion for the job and communication skills. The study also established that compared to MNCs, SMEs adopt a more inclusive approach to TM practices; the importance of informal talent practices, which provide flexibility for SMEs, was also noted. The study also highlighted the distinctive nature of the TM issues, challenges and constraints faced by internationally oriented Greek SMEs compared to large firms. The country's financial crisis posed immense challenges to all firms, yet by retaining their TM emphasis in difficult times, the SMEs in our study managed to substantially overcome them.

\section{References}

Beamond, M.T., Farndale, E. and Härtel, C.E.J. (2016), "MNE translation of corporate talent management strategies to subsidiaries in emerging economies", Journal of World Business, Vol.51 No.4, pp.499-510.

Bidwell, M. (2011), "Paying more to get less: the effects of external hiring versus internal mobility”, Administrative Science Quarterly, Vol.56 No.3, pp.369-407.

Bjorkman, I., Ehrnooth, M., Makela, K. and Sumelius, J. (2017), "Talent Management in Multinational Corporations" Collings, D.G., Mellahhi, K. and Cascio, W.F. (Eds.), The Oxford Handbook of Talent Management, Oxford University Press, Oxford, pp.461-477.

Boon, C., Paauwe, J., Boselie, P. and Den Hartog, D. (2009), "Institutional pressures and HRM: developing institutional fit", Personnel Review, Vol.38 No.5, pp.492-508.

Braun, V. and Clarke, V. (2006), "Using thematic analysis in psychology", Qualitative Research in Psychology, Vol.3, No.2, pp.77-101. 
Bryman, A. (2012), Social research methods. Oxford university press, Oxford.

Cappelli, P. (2009), “A supply chain model for talent management", People and Strategy, Vol.32 No.3, pp.4-7.

Cappelli, P. and Keller, J.R. (2014), “Talent management: conceptual approaches and practical challenges", Annual Review of Organisational Psychology and Organisational Behavior, Vol.1 No.1, pp.305-331.

Carbery, R. (2015), “Organisational learning”, Carbery, R. and Cross, C. (Eds.), Human Resource Development: A Concise Introduction, Red Globe Press, London, pp.84-102.

Cardon, M.S. and Stevens, C.E. (2004), "Managing human resources in small organisations: what do we know?", Human resource management review, Vol.14 No.3, pp.295-323.

Chung, K.L. and D’Annunzio-Green, N. (2018), “Talent management practices in small-and medium-sized enterprises in the hospitality sector", Worldwide Hospitality and Tourism Themes, Vol.10 No.1, pp.101-116.

Collings, D.G. and Mellahi, K. (2009), "Strategic talent management: a review and research agenda”, Human Resource Management Review, Vol.19 No 4, pp.304-313.

Correia, T., Dussault, G. and Pontes, C. (2015), "The impact of the financial crisis on human resources for health policies in three southern-Europe countries", Health Policy, Vol.119 No.12, pp.1600-1605.

Dacin, M.T, Goodstein, J. and Scott, W. (2002), "Institutional theory and institutional change: introduction to the special research forum", Academy of management journal, Vol.45 No.1, pp.45-57.

D'Amato, A. and Herzfeldt, R. (2008), "Learning orientation, organisational commitment and talent retention across generations: a study of European managers", Journal of Managerial Psychology, Vol.23 No.8, pp.929-963.

Dundon, T. and Wilkinson, A. (2009), "Employee participation”, Redman, T. and Wikinson, A. (Eds.), Contemporary Human Resource Management: Text and cases, FT, Prentice Hall, Essex, pp.405-424. 
Eibel, D. (2015), “The financial crisis, austerity policy and Greece”, Comparative Economic Research, Vol.18 No.4, pp.5-26.

European Commission. (2017), European economy: The ESM stability support programme: Greece, first and second reviews, Institutional Papers 064, Union Europe, Luxembourg.

European Commission. (2020), "User guide to the SME definition", available at: https://ec.europa.eu/regional_policy/sources/conferences/stateaid/sme/smedefinitionguide_en.pdf (accessed 20 October 2020).

Festing, M., Schäfer, L. and Scullion, H. (2013), “Talent management in medium-sized German companies: an explorative study and agenda for future research", The International Journal of Human Resource Management, Vol.24 No.9, pp.1872-1893.

Gallardo-Gallardo, E., Dries, N. and González-Cruz, T.F. (2013), "What is the meaning of 'talent' in the world of work?', Human Resource Management Review, Vol.23 No.4, pp.290-300.

Gallardo-Gallardo, E., Thunnissen, M. and Scullion, H. (2020), "Talent Management: context matters", International Journal of Human Resource Management, Vol.31 No.4, pp. 457473.

Gandz, J. (2006), "Talent development: the architecture of a talent pipeline that works", Ivey Business Journal, Vol.70 No.3, pp.1-4.

Harsch, K. and Festing, M. (2020), "Dynamic talent management capabilities and organisational agility-A qualitative exploration", Human Resource Management, Vol.59 No.1, pp.43-61.

Hatzis, A. (2018), “Greece's institutional trap”, Managerial and Decision Economics, Vol.39 No.8, pp.838-845.

Heneman, R.L., Tansky, J.W. and Camp, S.M. (2000), "Human resource management practices in small and medium-sized enterprises: unanswered questions and future research perspectives", Entrepreneurship theory and practice, Vol.25 No.1, pp.11-26. 
Holland, D. and Scullion, H. (2021), “Towards a talent retention model: mapping the building blocks of psychological contract to the three stages of the acquisition process", International Journal of Human Resource Management, (in press).

Holliday, A. (2002), "Distinguishing the voices of researchers and the people they research in writing a qualitative research", Miller, S, K. and Thompson, P (Eds.), Unity and Diversity in Language, London BAAL and Continuum, pp.125-137.

Jack, S., Hyman, J. and Osborne, F. (2006), "Small entrepreneurial ventures culture, change and the impact on HRM: A critical review", Human resource management review, Vol.16 No.4, pp.456-466.

Jackson, S.E. and Schuler, R.S. (1995), "Understanding human resource management in the context of organisations and their environments", Annual review of psychology, Vol.46 No.1, pp.237-264.

Jiang, T. and Iles, P. (2011), "Employer-brand equity, organisational attractiveness and talent management in the Zhejiang private sector, China", Journal of Technology Management in China, Vol.6 No.1, pp.97-110.

Joyce, W.F. and Slocum, J.W. (2012), “Top management talent, strategic capabilities, and firm performance", Organisational Dynamics, Vol.41 No.3, pp.183-193.

Khilji, S.E. and Schuler, R.S. (2017), “Talent management in the global context”, Collings, D. G., Mellahi, K. and Cascio, W. F. (Eds.), The Oxford Handbook of Talent Management, Oxford University Press, Oxford, pp.399-420.

Kirk, S., Howe-Walsh. L. and Scurry, T. (2020), "Reimagining global talent management? Considering the implications of context for research and practice", available at: https://www.emeraldgrouppublishing.com/journal/joepp/reimagining-global-talentmanagement-considering-implications-context-research-and (accessed 01 November 2020).

Kretsos, L. and Vogiatzoglou, M. (2015), "Lost in the ocean of deregulation? The Greek labour movement in a time of crisis", Relations Industrielles/Industrial Relations, Vol.70 No.2, pp.218-239. 
Krishnan, T.N. and Scullion, H. (2017), "Talent management and dynamic view of talent in small and medium enterprises", Human Resource Management Review, Vol.27 No.3, pp.431-441.

Lepak, D.P. and Snell, S.A. (1999), “The human resource architecture: toward a theory of human capital allocation and development", Academy of Management Review, Vol.24 No.1, pp.31-48.

Marinakou, E. and Giousmpasoglou, C. (2019), "Talent management and retention strategies in luxury hotels: evidence from four countries", International Journal of Contemporary Hospitality Management, Vol.31 No.10, pp.3855-3878.

Markovits, Y., Boer, D., Gerbers, S. and van Dick, R. (2017), "The impact of a lasting economic crisis on employee attitudes: a follow-up and extension", Athens Journal of Business \& Economics, Vol.3 No.2, pp.85-100.

Martin, G. and Sinclair, K. (2019), "Employer branding and corporate reputation management in global companies: theory and practice", Collings, D. G., Scullion, H. and Caligiuri, P. M. (Eds.), Global Talent Management, Routledge, New York, NY, pp.144-164.

Martin, J. and Schmidt, C. (2010), "How to keep your top talent", Harvard Business Review, Vol.88, No.5, pp.54-61.

Miles, M.B. and Huberman, A.M. (1994), Qualitative data analysis: an expanded sourcebook, Sage, Thousand Oaks, CA.

Mirvis, P.H. (1997), "Human resource management: leaders, laggards, and followers", Academy of Management Perspectives, Vol.11 No.2, pp.43-56.

Morgan, G. and Hauptmeier, M. (2014), "Institutional theory in comparative employment relations", Wilkinson, A., Wood, G. and Deeg R. (Eds.), The Oxford Handbook of Employment Relations, Oxford University Press, Oxford, pp.190-201.

Newell, S. (2005), "Recruitment and selection", Bach, S. (Ed.), Managing Human Resources: Personnel Management in Transition, Blackwell Publishing, Malden, MA, pp.115-142. 
Nijs, S., Gallardo-Gallardo, E., Dries, N. and Sels, L. (2014), “A multidisciplinary review into the definition, operationalisation, and measurement of talent", Journal of World Business, Vol.49 No.2, pp.180-191.

OECD. (2016), OECD economic surveys: Greece 2016, OECD Publishing, Paris.

OECD. (2018a), "Skills for jobs", available at: https://www.oecdskillsforjobsdatabase.org/data/country_notes/Greece $\% 20$ country $\% 20$ note.pdf (accessed 09 November 2020).

OECD. (2018b), OECD economic surveys: Greece 2018, OECD Publishing, Paris.

Ogbonna, E. and Harris, L.C. (2015), "Subcultural tensions in managing organisational culture: a study of an English Premier League football organisation", Human Resource Management Journal, Vol.25 No.2, pp.217-232.

Oliver, C. (1991), "Strategic responses to institutional processes", Academy of Management Review, Vol.16 No.1, pp.145-179.

Paauwe, J. and Boselie, P. (2003), 'Challenging 'strategic HRM' and the relevance of the institutional setting”, Human Resource Management Journal, Vol.13 No.3, pp.56-70.

Pagoulatos, G. (2020), "EMU and the Greek crisis: testing the extreme limits of an asymmetric union", Journal of European Integration, Vol.42 No.3, pp.363-379.

Pate, J. and Scullion, H. (2018), “The flexpatriate psychological contract: a literature review and future research agenda", The International Journal of Human Resource Management, Vol.29 No.8, pp.1402-1425.

Patton, M. (1990). Qualitative evaluation and research methods. Sage, London.

Piansoongnern, O., Anurit, P. and Kuiyawattananonta, S. (2011), "Talent management in Thai cement companies: a study of strategies and factors influencing employee engagement", African Journal of Business Management, Vol.5 No.5, pp.1578-1583. 
Pitelis, C.N. (2012), “On PIIGs, GAFFs, and BRICs: an insider-outsider's perspective on structural and institutional foundations of the Greek crisis", Contributions to Political Economy, Vol.31 No.1, pp.77-89.

Pratt, M.G., Rockmann, K.W. and Kaufmann, J.B. (2006), "Professional identity: the role of work and identity learning cycles in the customisation of identity among medical residents", The Academy of Management Journal, Vol.49, No.2, pp.235-262.

Psychogios, A., Brewster, C., Missopoulos, F., Kohont, A., Vatchkova, E. and Slavic, A. (2014), "Industrial relations in South-Eastern Europe: disaggregating the contexts", The International Journal of Human Resource Management, Vol.25 No.11, pp.1592-1612.

Sainis, G., Haritos, G., Kriemadis, T. and Fowler, M. (2017), “The quality journey for Greek SMEs and their financial performance", Production \& Manufacturing Research, Vol.5 No.1, pp.306-327.

Saunders, M.N. and Townsend, K. (2016), "Reporting and justifying the number of interview participants in organisation and workplace research." British Journal of Management, Vol.27 No.4, pp.836-852.

Saunders, M.N., Thornhill, A. and Lewis, P. (2009), Research Methods for Business Students, FT Prentice-Hall, London.

Savov, R., Lančarič, D. and Kozáková, J. (2020), “Size of the company as the main determinant of talent management in Slovakia”, Journal of Risk and Financial Management, Vol.13 No.3, pp.1-14.

Silzer, R. and Dowell, B.E. (2010), "Strategic talent management matters", Silzer, R. and Dowell, B. E, Strategy-Driven Talent Management: A Leadership Imperative, JosseyBass, San Francisco, CA, pp.3-72.

Skuza, A., Scullion, H. and Collings, D.G. (2016), “Talent management in Europe”, Dickmann, M., Brewster, C. and Sparrow, P. (Eds.), International Human Resource Management: Contemporary HR Issues in Europe, Routledge, New York, NY, pp.329-353. 
Sparrow, P., Scullion, H. and Tarique, I. (2014), "Introduction: challenges for the field of strategic talent management”, Sparrow, P., Scullion, H. and Tarique, I. (Eds), Strategic Talent Management: Contemporary Issues in International Context, Cambridge University Press, Cambridge, pp.3-35.

Sparrow, P.R. and Makram, H. (2015), "What is the value of talent management? Building value-driven processes within a talent management architecture", Human Resource Management Review, Vol.25 No.3, pp.249-263.

Stahl, G.K., Björkman, I., Farndale, E., Morris, S.S., Paauwe, J., Stiles, P., Trevor, J. and Wright, P.M. (2012), “Six principles of effective global talent management”, MIT Sloan Management Review, Vol.53 No.2, pp.24-32.

Stamouli, N. (2020), “Greece's reverse brain drain: government scheme offers cash to educated Greeks who moved abroad during the crisis", available at: https://www.politico.eu/article/greece-reverse-brain-drain-skills-young-peoplefinancial-crisis/ (accessed 11 October 2020).

Statista. (2021), "Number of small and medium-sized enterprises (SMEs) in the European Union in 2018 by size", available at: https://www.statista.com/statistics/878412/numberof-smes-in-europe-by-size/ (accessed 12 April 2021).

Stavrou, E.T. and Papalexandris, N. (2016), "Mediterranean HRM: key trends and challenges", Dickmann, M., Brewster, C. and Sparrow, P. (Eds.), International Human Resource Management: Contemporary HR Issues in Europe, Routledge, New York, pp.49-70.

Storey, D.J., Saridakis, G., Sen-Gupta, S., Edwards, P.K. and Blackburn, R.A. (2010), "Linking HR formality with employee job quality: the role of firm and workplace size", Human Resource Management, Vol.49 No.2, pp.305-329.

Tarique, I. and Schuler, R.S. (2010), "Global talent management: literature review, integrative framework, and suggestions for further research", Journal of World Business, Vol.45 No.2, pp.122-133. 
Tasoulis, K., Krepapa, A. and Stewart, M.M. (2019), "Leadership integrity and the role of human resource management in Greece: gatekeeper or bystander?", Thunderbird International Business Review, Vol.61 No.3, pp.491-503.

Teague, P. and Roche, W.K. (2014), "Recessionary bundles: HR practices in the Irish economic crisis", Human Resource Management Journal, Vol.24 No.2, pp.176-192.

Theocharis, Y. and Deth, J.W.van. (2015), “A modern tragedy? Institutional causes and democratic consequences of the Greek crisis”, Representation, Vol.51 No.1, pp.63-79.

Theodoropoulos, D., Kyridis, A., Zagkos, C. and Konstantinidou, Z. (2014), “Brain drain” phenomenon in Greece: young Greek scientists on their way to immigration in an era of "crisis". Attitudes, opinions and beliefs towards the prospect of migration", Journal of Education and Human Development, Vol.3 No.4, pp.229-248.

Theriou, G. and Chatzoudes, D. (2015), "Exploring the entrepreneurship-performance relationship: evidence from Greek SMEs", Journal of Small Business and Enterprise Development, Vol.22 No.2, pp.352-375.

Tsilika, T., Kakouris, A., Apostolopoulos, N. and Dermatis, Z. (2020), "Entrepreneurial bricolage in the aftermath of a shock: insights from Greek SMEs", Journal of Small Business \& Entrepreneurship, Vol.32 No.6, pp.635-652.

Vaiman, V. and Brewster, C. (2015), "How far do cultural differences explain the differences between nations? Implications for HRM", The International Journal of Human Resource Management, Vol.26 No.2, pp.151-164.

Vaiman, V., Sparrow, P., Schuler, R. and Collings, D.G. (2018), Macro talent management: a global perspective on managing talent in developed markets, Routledge, New York, NY.

Valverde, M., Scullion, H. and Ryan, G. (2013), "Talent management in Spanish medium-sized organisations", The International Journal of Human Resource Management, Vol.24 No.9, pp.1832-1852. 
Vlados, C. and Chatzinikolaou, D. (2020), "Institutional dynamics and economic development in Greece: an acemoglian approach", Research in Applied Economics, Vol.12 No.1, pp.12-32.

Voumvaki, J., Koutouzou, A., Sakkas, G., Konstantopoulou, N. and Krompas, I. (2020), "SMEs: Survey of Greek business trends - Special focus: Innovation", available at: https://www.nbg.gr/english/the-group/press-office/espot/reports/Documents/SMEs_Innovation_en.pdf(accessed 11 April 2021).

Williamson, I.O., Cable, D.M. and Aldrich, H.E. (2002), "Smaller but not necessarily weaker: how small businesses can overcome barriers to recruitment”, Katz, J. and Welbourne, T.M. (Eds.), Managing people in entrepreneurial organisations: Learning from the merger of entrepreneurship and human resource management, Jai Press, Amsterdam, pp.83-106.

Wöcke, A., Bendixen, M. and Rijamampianina, R. (2007), "Building flexibility into multinational human resource strategy: a study of four South African multi-national enterprises", International Journal of Human Resource Management, Vol.18 No.5, pp.829-844.

Xian, H. (2008), "Lost in translation? Language culture and the roles of translator in crosscultural management research", Qualitative Research in Organisation, Vol.3 No.3, pp.231-245. 
Table 1. Background of sampled companies

\begin{tabular}{|c|c|c|c|c|}
\hline Cases & Industry & Location & Year of establishment & $\begin{array}{l}\text { Number of } \\
\text { employees }\end{array}$ \\
\hline $\mathrm{A}$ & Electronics & North Greece & 1991 & 82 \\
\hline B & IT consultancy & North Greece & 2003 & 55 \\
\hline $\mathrm{C}$ & $\begin{array}{l}\text { Chemicals' } \\
\text { manufacturer }\end{array}$ & Central Greece & 1959 & 100 \\
\hline $\mathrm{D}$ & $\begin{array}{c}\text { Industrial } \\
\text { manufacturer }\end{array}$ & Central Greece & 1962 & 100 \\
\hline $\mathrm{E}$ & MOT centre & South Greece & 2003 & 93 \\
\hline $\mathrm{F}$ & Holiday Resort & South Greece & 1992 & 120 \\
\hline
\end{tabular}


Table 2. Coding framework

\begin{tabular}{|c|c|c|c|c|}
\hline $\begin{array}{l}\text { Research } \\
\text { Inquiry }\end{array}$ & $\begin{array}{c}\text { Illustrative } \\
\text { Quotes }\end{array}$ & $\begin{array}{l}\text { First-Order } \\
\text { Codes }\end{array}$ & $\begin{array}{c}\text { Consolidating Codes - } \\
\text { Creating } \\
\text { Conceptual } \\
\text { Categories }\end{array}$ & Key Themes \\
\hline \multirow{3}{*}{$\begin{array}{l}\text { How does } \\
\text { Greece's } \\
\text { institutional } \\
\text { context } \\
\text { shape talent } \\
\text { acquisition, } \\
\text { development } \\
\text { and } \\
\text { retention } \\
\text { among } \\
\text { SMEs in the } \\
\text { country? }\end{array}$} & $\begin{array}{l}\text { Despite the } \\
\text { economic down- } \\
\text { turn and other } \\
\text { sociocultural } \\
\text { norms and } \\
\text { constraints, we as } \\
\text { international } \\
\text { corporations } \\
\text { must do the } \\
\text { needful (CEO A). }\end{array}$ & $\begin{array}{l}\text { Unwillingness to } \\
\text { invest } \\
\text { Closed economy } \\
\text { Labour act }\end{array}$ & $\begin{array}{l}\text { Macroeconomic } \\
\text { decline } \\
\text { Overwhelming labour } \\
\text { law }\end{array}$ & $\begin{array}{l}\text { Institutional } \\
\text { Context }\end{array}$ \\
\hline & $\begin{array}{l}\text { We initially } \\
\text { advertise a job } \\
\text { opening online in } \\
\text { various job } \\
\text { websites (HR } \\
\text { Manager C). } \\
\text { We are looking } \\
\text { for people who } \\
\text { are honest, kind } \\
\text { and have passion } \\
\text { for their job } \\
\text { (CEO A). } \\
\text { Our American } \\
\text { partner will } \\
\text { complete a } \\
\text { telephone } \\
\text { interview with the } \\
\text { finalists to check } \\
\text { their capacity } \\
\text { and ability (CEO } \\
\text { B). }\end{array}$ & $\begin{array}{l}\text { Advertise online, } \\
\text { recruitment, } \\
\text { university } \\
\text { contacts, } \\
\text { agencies, } \\
\text { referrals from } \\
\text { staff. } \\
\text { Passion for job, } \\
\text { communication } \\
\text { skills, } \\
\text { confidence, } \\
\text { honesty, } \\
\text { customer } \\
\text { service skills, } \\
\text { kind, smiley } \\
\text { Face-to-face and } \\
\text { phone interview, } \\
\text { aptitude test }\end{array}$ & $\begin{array}{l}\text { Idiosyncratic } \\
\text { qualities }\end{array}$ & $\begin{array}{l}\text { Talent } \\
\text { Acquisition }\end{array}$ \\
\hline & $\begin{array}{l}\text { Offer } \\
\text { opportunities for } \\
\text { development to } \\
\text { all employees } \\
\text { regardless of } \\
\text { position (HR } \\
\text { Manager F). } \\
\text { Responsibility to } \\
\text { coach my team }\end{array}$ & $\begin{array}{l}\text { Department } \\
\text { level, employee } \\
\text { level } \\
\text { Continuous, ad- } \\
\text { hoc } \\
\text { Everyone, talents } \\
\text { managers }\end{array}$ & $\begin{array}{l}\text { Training need } \\
\text { identification } \\
\text { Training frequency } \\
\text { Target group } \\
\text { Training method and } \\
\text { evaluation }\end{array}$ & $\begin{array}{l}\text { Talent } \\
\text { Development }\end{array}$ \\
\hline
\end{tabular}




\begin{tabular}{|c|c|c|c|}
\hline $\begin{array}{l}\text { (Line Manager } \\
\text { F). } \\
\text { Training is } \\
\text { evaluated by both } \\
\text { the trainer and } \\
\text { the trainees (HR } \\
\text { Manager A). }\end{array}$ & $\begin{array}{l}\text { On-the-job, } \\
\text { coaching, } \\
\text { learning, } \\
\text { behaviour, } \\
\text { reaction, result }\end{array}$ & & \\
\hline $\begin{array}{l}\text { Monetary and } \\
\text { non-monetary } \\
\text { incentives are } \\
\text { offered to all } \\
\text { employees (Line } \\
\text { Manager C). } \\
\text { Financial and } \\
\text { non-financial } \\
\text { rewards to our } \\
\text { people, e.g. } \\
\text { competitive } \\
\text { salary, health } \\
\text { insurance, } \\
\text { training } \\
\text { opportunities and } \\
\text { promotions (HR } \\
\text { Manager E). }\end{array}$ & $\begin{array}{l}\text { Bonuses, laptops } \\
\text { competitive pay, } \\
\text { health insurance, } \\
\text { paid travel } \\
\text { expenses, } \\
\text { corporate cars, } \\
\text { pay increase, } \\
\text { gift, overtime } \\
\text { pay } \\
\text { Training, } \\
\text { promotion, } \\
\text { recognition, } \\
\text { coaching, } \\
\text { additional } \\
\text { holidays, } \\
\text { job rotation, } \\
\text { career } \\
\text { progression, } \\
\text { flexible } \\
\text { workload, } \\
\text { collaboration } \\
\text { with universities, } \\
\text { safe work } \\
\text { environment }\end{array}$ & $\begin{array}{l}\text { Extrinsic reward } \\
\text { Intrinsic reward }\end{array}$ & $\begin{array}{l}\text { Talent } \\
\text { Retention }\end{array}$ \\
\hline
\end{tabular}

